\title{
TTR
}

Traduction, terminologie, re?daction

\section{The Inkas as Tyrants: The Construction of a Twisted Representation}

\section{Les Incas perçus comme tyrans: la construction d'une représentation trompeuse}

\section{Lydia Fossa}

Volume 18, numéro 1, 1er semestre 2005

Traductions et représentations : Parcours dans l'espace hispanique II Translations and Representations: Exploring the Hispanic World II

URI : https://id.erudit.org/iderudit/014366ar

DOI : https://doi.org/10.7202/014366ar

Aller au sommaire du numéro

Éditeur(s)

Association canadienne de traductologie

ISSN

0835-8443 (imprimé)

1708-2188 (numérique)

Découvrir la revue

Citer cet article

Fossa, L. (2005). The Inkas as Tyrants: The Construction of a Twisted Representation. TTR, 18(1), 33-54. https://doi.org/10.7202/014366ar
Résumé de l'article

Le chroniqueur Pedro Sarmiento de Gamboa écrivit en 1571 une histoire des Incas pour prouver leur tyrannie. La chose était nécessaire pour convaincre le Roi qu'il avait tous les droits sur leurs terres, leurs biens et leur peuple. Cette chronique constitue un bon exemple du travail de représentation: celle-ci, en effet, lorsque les questions politiques priment, ne doit pas nécessairement refléter la réalité. Mon article analyse cette représentation trompeuse et explore les motifs pour lesquels Sarmiento dut faire authentifier sa version des faits par les kuraka. 


\section{The Inkas as Tyrants: The Construction of a Twisted Representation}

\section{Lydia Fossa}

\section{Pedro Sarmiento de Gamboa's profile}

When Sarmiento was about 25 years old, he started the seafaring voyages that kept him busy for the rest of his life. He died at sea when he was 60, off the coasts of Lisbon. He was the Admiral that would escort ships transporting gold and silver across the Atlantic. He did not complete his first trip in this position, but his rank of Admiral was an indication of how high he had risen within the Spanish administration.

In 1557, after a two-year sojourn in Mexico, Sarmiento sailed to Peru. Ten years later, in 1567, he was on board again as Captain of one of the ships, and most importantly, as Cosmographer of Alvaro de Mendaña's expedition. He left Callao in search for a western route to Europe across the Pacific that would provide an alternative to the transatlantic one, plagued by pirates and corsaries. They did reach the Solomon Islands, and if his indications had been followed, they would have arrived at the Australian shores. Once he returned to Peru, he joined Viceroy Francisco de Toledo's project of "visiting” the land. During these land trips he collected the data that he then rendered in his Historia General llamada Indica.

The 1580s mark his desire to find an Atlantic pass far from the Caribbean routes, which were plagued by inconveniences, especially if travelling from Peru or any Pacific port. He did find Magellan's pass which he explored, and unsuccesfully intended to populate. In 1586, demoralized, he returned to Spain. But his ship was boarded by Francis 
Drake, a British pirate, and he was taken to London as prisoner. In 1587, after this ordeal and while travelling to Spain again, he was detained by Frenchmen and held captive for three years. He finally made the full trip to Spain, and in 1591 he was appointed as Admiral of the ships carrying American riches across the Atlantic. He died in 1592. He was an able seafarer, a full-fledged Cosmographer, and an obedient subject of the King of Spain. He did have a few harsh encounters with the Spanish Inquisition, but he was never jailed or detained as a result of these matters.

As part of his duties towards the King, he composed the Inka history required by the Viceroy. One might wonder why a Cosmographer such as he transmuted into a Historian. He explains that his endeavor was to write a description of the land so a better organization could be put in place, choosing the best locations for cities or posts that would lead the territorial administration. When preparing to write the geographical profile of the land, he was ordered to start with a history of the Inkas that would demean them. So the technical description was postponed, but the subtitle of "First Part" he gave it remained. The Historia General llamada Indica was the "Second Part," the only one found until today. This tale did not follow the usual trend of the period, but constructed a representation of the Inkas as tyrants. In order to "prove" that he was telling a truthful story, he required a declaration under oath of the main kuraka ${ }^{1}$ indicating that his history told the truth. This confirmation had never before been needed by other chroniclers.

\section{Historical Context}

The phrase: "descargo de vuestra real conciencia” (Sarmiento, 1988, p. 22), which in English would read something like the "unloading of the Royal Conscience," seems a little awkward today. It sounds uncanny because in modern society, the powers of current political leaders no longer emanate from divine sources. But in the sixteenth century, monarchs had been entrusted the conduction of His flock by God Himself. Spanish kings were especially weighed by this assignment, and Fernando and Isabella had been awarded the title of "Catholic Kings" for their defense of the faith in the Reconquest of the peninsula from the Moors. Charles the Fifth and Phillip the Second

\footnotetext{
${ }^{1}$ Kuraka or Curaca: "Señor principal de vasallos” (Nobleman, lord of vassals) (Santo Tomás, [1560] 1951, p. 277).
} 
tried as much as they could to follow in the footsteps of their forefathers. The Spanish Kings had to be models of Catholicism, and that meant that their behavior had to be as saintly as possible. They had to gain the sponsorship of the Papacy.

In the first half of the sixteenth century, a wave of critique begun by Dominican priests disseminated the information that indigenous populations in the Indies had been decimated. The conquerors, subjects of the Spanish crown, had not followed a Christian ideal in spreading the word of the Catholic God but had killed, robbed, and assaulted in order to occupy the land. They had cruelly assassinated indigenous leaders in order to terrorize entire populations. These crimes were committed in spite of the Royal ordinances known as the Laws of Burgos, enacted by Queen Isabella in 1512 to protect kuraka or caciques, as they were known in Central America (Morales Padrón, 1979, pp. 313-314).

Since the early sixteenth century, voices were raised, wondering and thundering, namely that of Fray Antón Montesino in Hispaniola in 1511 (Pérez, 1986, p. 63), about the legality not only of the appropriation of lands, peoples, and riches, but of the sheer presence of the Spaniards in the Indies. Bartolomé de las Casas continued with even more vigor to condemn the atrocities wrought by the Spaniards. He was converted to the cause of the defense of the indigenous populations by Montesino, and in 1522 (Pérez, 1986, p. 63) joined him as brother of the Dominican Order. Another Dominican who spoke out against the conquerors was Fray Francisco de Vitoria, a distinguished professor at Salamanca in the 1530s and 1540s. Vitoria's voice was heard beyond the cloisters as early as 1534, and his followers continued with their protests until 1569 (Pereña, 1984). The King could not be unaware of these manifestations, since many letters regarding these matters were written to him. And the Royal Conscience was feeling very heavy indeed.

The Spanish King then convened a hearing in which all the advantages and disadvantages of the enterprise would be discussed. This intellectual confrontation followed the Thomist tradition, dear to philosophers of the time. Fray Bartolomé de las Casas and don Juan de Sepúlveda immersed themselves in this discussion which also included a series of assistants. This was carried out between August 15 and midSeptember 1550 in Valladolid (Pérez, 1986 p. 204) before magistrates, prelates, and the King himself. Sepúlveda defended the position of the 
lawful titles of the Crown to invade, conquer, and occupy the Indies and Firm Land, while Las Casas presented the opposite view, stating that indigenous lords were lawful leaders of their people, had never attacked Spaniards or occupied Spanish lands, and therefore, could not be treated as enemies. His ideas were known as the "duda indiana" or "Indian doubt." Furthermore, he insisted that the forceful ways in which Catholicism had been imposed on them was counterproductive. The ideological battle had no obvious winner, but generated several measures that protected the indigenous populations from the greed of ambitious Spaniards (Pérez, 1986, p. 204).

What spurred on the dispute and the writing of the laws was the impressive diminution of the indigenous population. This fact decisively impacted the tribute collected, so the Crown was directly affected by it. The reasons for the decimation of the population were examined, and excessive labor was identified as one of the main causes. Another factor was the forced migration from one region to the other or within regions with different climates. Abuses of all kinds that can be synthesized as enslavement in its worst conditions instigated by unbound ambition were identified and intended to be curbed.

High mortality had another effect on the Crown: since most of the dying indigenous peoples were dying without baptism, it was believed that they were going to Hell. The King and prelates, and even the Pope, considered this to be the responsibility of the Spanish Crown and the Spanish Church charged with the task of evangelization. This matter was examined with the utmost care, and measures were taken to prevent it: through naming of bishops for the newly organized bishoprics, which led to the construction of monasteries, the designation of friars to this task, the learning of indigenous languages, among others.

Before that, in 1542, the New Laws had been enacted. That body of legislation was inspired on the discussion, especially the ideas and principles proposed by Las Casas, who had spent most of his life in the Indies, and was familiar with the issues at hand. The New Laws generated a revolution in Peru, since they drastically minimized the prerogatives of the Spanish first-comers. Thus the latter reacted violently, asking to participate in the discussion or the liberalization of the measures. The New Laws were abrogated after much bloodshed, though ultimately were never really applied. At least the situation never reverted to the initial brutality of the abuses which characterized the 
conquest and first decades of colonization. The encomenderos, the affected party, sent an envoy to change the New Laws. Indigenous leaders also united in defense of the application of the New Laws which somewhat protected them and their peoples. Fray Tomás de San Martín, a Dominican friar, was their representative before the Crown. These meetings took place in October 1550, in Spain, and were known as the meetings for the perpetuity of encomiendas. They formed part of the second phase of the Sepúlveda-Las Casas discussions (Pérez, 1986, p. 204).

Still in 1560, some distinguished members of the Dominican Order received a power of representation from the kuraka. Fray Domingo de Santo Tomás traveled to Spain, and with Fray Bartolomé de Las Casas, presented the kuraka's position before the King. They were decidedly opposed to their counterparts' offer to buy the perpetuity of property (land and Indians) from the King. The priests did not succeed, but their tempting offer, that of the kuraka, made the King realize that the encomenderos could never fulfill their promise of buying at the prices offered. The King, in 1561, sent a message to his Viceroy in Peru indicating his desire to pay greater attention to Santo Domingo and the kuraka (Pérez, 1986, pp. 297-298). Although not a victory, at least this step represented a moderation of the ambitious encomenderos' plan, which would have been highly detrimental to the indigenous populations.

In 1569 Viceroy Francisco de Toledo arrived in Peru, eager to end the lengthy discussion about the duda indiana (Indian doubt). Most of all, his instructions were to press friars to refrain from making political declarations from pulpits and confessionaries regarding this delicate subject (Lohmann, 1984, p. 647). His personal aim, based on and even surpassing his instructions, was to deal with the matter from its two main aspects. On one hand, he wanted to "draw up a comprehensive report in which conclusive evidence would be presented about the illegitimate Inka government that would uncover the false Lascasian thesis of a supposed usurpation of the inherent rights of Inka sovereigns...” (Lohmann, 1984, p. 647). ${ }^{2}$ On the other hand, Viceroy

2 My translation of: “... allegar una probanza exhaustiva en la que se acumularan pruebas irrefragables y concluyentes del gobierno ilegítimo de suyo de los Incas, quedando así al descubierto la falsedad de la tesis lascasiana sobre una supuesta usurpasiòn de los derechos inherentes a los soberanos 
Toledo wanted to exterminate the Inka group that had found refuge in Vilcabamba (Lohmann, 1984, p. 647). He had also been instructed to organize a visit to the land, to redistribute the lands and peoples (encomiendas) among deserving Spaniards. Toledo found several experts in the land to accompany him on this Visita; Pedro Sarmiento de Gamboa was one of them.

\section{The Viceroy and the Appointment}

In his text, Sarmiento explains the reasons for the Visita, and for his appointment: "And in order that Your Majesty would be informed with little effort and much gusto, and those with a different belief be aware of their errors, I was ordered by viceroy Don Francisco de Toledo, whom I follow and serve in this General Visit, to take charge of this business and write the history of the deeds of the twelve Inkas of this land and of the origin of these indigenous peoples, until their end" (1988, p. 23). ${ }^{3}$ The motivation to write the Inka history is to offer the account that would convince those with an opinion contrary to Sarmiento's, and make them see the true facts. Also, was the aim to calm any anxiousness on the King's part regarding the legality of the invasion and usurpation. He writes a history with a clear objective: to serve his King by giving him a well-written history that would render previous versions ineffective and untruthful. The appeal to truth comes immediately after the introductory sentence: "I have complied with the Viceroy's orders, and this is the history, made with the appropriate curiosity and diligence, which will be observed through its process and in its ratification by witnesses, as Your Majesty will see” (1988, p. 23). ${ }^{4}$ The appeal to indigenous witnesses certifying a text written by a Spaniard was unheard of until Sarmiento's endeavor. Indigenous "nobility" and recognized representatives had been quoted before as

incaicos...” [henceforth all translations will be mine unless otherwise specified].

3 "Y para que Vuestra Majestad fuese con poco cansancio y con mucho gusto informado y los demás que son de contrario parecer, desengañados, me fue mandado por el virrey Don Francisco de Toledo, a quien yo sigo y sirvo en esta visita general, que tomase a mi cargo este negocio e hiciese la historia de los hechos de los doce incas de esta tierra y del origen de los naturales de ella hasta su fin."

4 "La cual yo hice y es ésta, con la curiosidad y diligencia que convenía, como en el proceso de ella y en la ratificación de los testigos Vuestra Majestad verá.” 
informants in order to establish authenticity, and to confirm Spanish writers had been in the land while compiling their reports and chronicles. But a ceremony of authentication of this kind, as described by Sarmiento, was the first. Why did he need such a display of certification? He was going to write a history that denied all that had been written before, and that was evident to those living in the Andes at the time: "And the fact of the truth will be certified..." (1988, p. 23).

The "truth" that Sarmiento wanted to convey both to the King and to incredulous readers, is stated by him in his opening paragraphs:

... the appalling and more than inhuman tyranny of these Inkas, and their private curacas, who are not nor ever were natural lords but imposed by Tupac Inca Yupanqui, the greatest and most atrocious and harmful tyrant of all. And the curacas were and are the greatest of tyrants, as in the history it will appear, clear and certainly in a way that proves the tyranny, and also of being foreigners in Cuzco and of having exercised violence on the people living in the same valley of Cuzco and in all of them from Quito down to Chile by force of arms, and of having made themselves Incas without the consent or the election of indigenous peoples. (1988, p. 23) ${ }^{6}$

Ironically, he transfers to Inkas and kuraka a description that better fits Spanish conquerors.

\section{The Historian and the Translators/Decodifiers}

Interestingly enough, the truth, so dear to Sarmiento, is something he already possesses. It had to be certified a priori by kuraka. But, he could not have obtained the material for his history directly, since he did not speak Quechua or Aimara, two of the most widely spoken indigenous languages. He had to count on the intervention of interpreters, most of them of Mestizo extraction, or indigenous noble

5 "Y se certificará del hecho de la verdad..."

6 “...la pésima y más que inhumana tiranía de estos incas y de los curacas particulares, los cuales no son ni nunca fueron señores naturales, sino puestos por Tupac Inca Yupanqui, el mayor y más atroz y dañoso tirano de todos. Y los curacas fueron y ahora son grandísimos tiranos, como en la historia aparecerá claro y cierto de suerte que probada la tiranía, así de ser extranjeros del Cuzco y haber violentado a los naturales del mismo valle del Cuzco y a todos los demás desde Quito hasta Chile por fuerza de armas y haberse hecho incas sin consentimiento ni elección de los naturales.” 
children raised by friars. This means that we have two instances of translation: the first when the information was obtained orally from indigenous informers, and the second when that written information was read and translated to kuraka for their certification. Sarmiento refers to these two phases when he writes: “... in the process of writing it, and in its ratification by the witnesses...” (1988, p. 23). ${ }^{7}$

The last part of the printed text is entitled "Fe de la probanza y verificación de esta historia" (Faith of the Proof and Verification of this History). It is, thus, the authentication document that accompanying it. This document was signed by Notary Alvaro Ruiz de Navamuel, in Cuzco, on February 29, 1572. The formal declaration is preceded by an Introduction by Sarmiento, in which he confirms that he "has drawn and reduced to history the general chronicle of the origin and genealogy of the Inkas and of the particular deed each one of them did in its time...” (1988, p. 172-173). ${ }^{9}$ He implies by this that there existed a general Inka chronicle which he extracted and edited as his Historia General llamada Indica. He does not say, though, if this chronicle was written in Spanish, was knotted in khipu ${ }^{10}$, or was passed on orally. But he does provide some details about the location of his sources:

... which history I have extracted of the information and other findings that, upon orders of Your Excellency, have been made in the Xauxa valley and in the city of Huamanga and in other parts that

7 “... en el proceso de ella [la historia] y en la ratificación de los testigos...”

${ }^{8}$ In Spanish "sacar," to take out, to extract. As it is used metaphorically, I believe the English verb "to draw" is closer in meaning to the Spanish locution. According to Covarrubias, it is: "Sacar. Es quitar alguna cosa o sacarla de donde está escondida; está tomada de la metáfora de saco, de donde vamos echando fuera lo que está dentro, y esto se dice propiamente sacar. Por alusión tiene infinitas significaciones, que ni hay para qué detenernos en ellas.” (My translation: Sacar. It is to take off something or draw it from where it is hidden; it is a metaphor of sack, from where we draw what is inside, and this is properly to take out. As allusion it has infinite meanings, and there is no need to give them in great detail.) ([1611] 1995, p. 875).

9 “... yo he sacado y reducido a historia la crónica general del origen y descendencia de los incas y de los hechos particulares que cada uno hizo en su tiempo...”

${ }^{10}$ Khipu or Qquipu: “Ñudo o quenta por ñudos” (Knot, or accounting by knots). (González Holguín, ([1608] 1989, p. 309) 
Your Excellency has been inspecting, especially in this city of Cuzco, where the Inkas had their continuous habitation, and where there is more information about their deeds; where the mitmaq brought over from all the provinces by the Inka converged, and the true memory of their past was held by their ayllus. $\left(1988\right.$, p. 173) ${ }^{11}$

This information leads us to believe that he had access to documents, reports or informaciones that had already been written before the arrival of the visiting retinue, and presented to Viceroy Toledo. What he says of Cuzco is quite revealing: it was there that he found most of the information he used. Several previous Inka histories had been written there; those of Pedro de Cieza de León (1550), and Juan Díez de Betanzos (1551-1558), among others. It is highly probable that copies of those finished texts or previous versions were in the hands of Viceroy Toledo by the 1570s. Similarities between Betanzos's and Sarmiento's text point in that direction (Fossa, 2005; Nowack, 2002). He insists that his history has been written from "information and inquiries made with the Indians and other persons" (1988, p. 173). ${ }^{12}$ Those inquiries had to be carried out with the help of interpreters who translated questions from Spanish into one of the main languages spoken by indigenous populations, Quechua or Aimara. Then, the answers went from indigenous languages into Spanish to be recorded in a written text. It is quite possible that the information provided by local Andeans was stored in khipu, and transcoded into oral language in order to answer the questions posed by the Spanish officer. If Sarmiento used a report already written in Spanish, the translation and transcoding activities took place before his time. Since he does not mention them as part of his tasks, it might well be said that he simply used a previously written history, which he only edited, adding a few items he found important. Nevertheless, he insists that, upon orders of the Viceroy, "in order to understand if the said history conforms to the

11 "La cual historia yo he sacado de las informaciones y otras averiguaciones que por mando de Vuestra Excelencia se han hecho en el valle de Xauxa y en la ciudad de Huamanga y en otras partes por donde Vuestra Excelencia ha venido visitando, y principalmente en esta ciudad del Cuzco, donde los incas tuvieron su continua habitación y hay más noticia de sus hechos, y donde concurrieron los mitimaes de todas las provincias que los dichos incas trajeron, y quedó la verdadera memoria con sus ayllus.”

12 "informaciones y averiguaciones que se han hecho con los indios y otras personas..." 
said information and inquiries made with the Indians and other persons of this city and other places...” (1988, p. 173), ${ }^{13}$ a certification has to take place. Here we have the second phase of translation and interpretation, when Sarmiento's text is read aloud in Spanish and translated into Quechua for Cuzco kuraka to understand and certify:

... he [the Viceroy] ordered Doctor Loarte, Court Mayor of His Majesty, to convoke the most outstanding and of better understanding Indians of the twelve ayllus and descendants of the twelve Incas and other persons according to his criteria, and with the present secretary before me, have the said history read to them and be declared by interpreter and lengua of the said Indians, so all of them together see and talk among themselves to discuss if it conforms to the truth they know. And if there is something to be corrected and amended, and if it seemed to be contrary to what they know, be it amended and corrected. (1988, p. 173) ${ }^{14}$

Then, each one of the paragraphs was discussed and agreed upon: "And as each chapter was read out loud [in Spanish], it was declaimed [in Quechua] by the said lengua; the Indians talked and discussed among themselves, about all and each one of the said chapters, as declared in the lengua” (1988, p. 176). ${ }^{15}$ This procedure took two days: “... it was read and finished reading and declared that said day and the following...” (1988, p. 176). ${ }^{16}$ There were a few items corrected, such

13 “... para que se entienda si la dicha historia es conforme a las dichas informaciones y averiguaciones que se han hecho con los indios y otras personas de esta ciudad y otras partes...”

14 “... mandaba y mandó [el Virrey] que el doctor Loarte, alcalde de corte de Su Majestad, haga aparecer ante sí los indios más principales y de mejor entendimiento de los doce ayllus y descendencias de los doce incas y otras personas que le pareciere, y a todos, estando juntos por ante mí el presente secretario, les haga leer la dicha historia y que se le declare por intérprete y lengua de los dichos indios, para que todos juntos vean y platiquen entre sí si es conforme a la verdad que ellos saben. Y si hay alguna cosa que corregir y enmendar, y lo que pareciere que está en contrario a lo que ellos saben, se enmiende y corrija.”

15 "Y como se iba leyendo [en castellano], se les iba declarando [en quechua] por el dicho lengua cada capítulo por sí; sobre lo cual y sobre cada uno de los dichos capítulos los dichos indios iban platicando y confiriendo entre sí, como lo declaró el dicho lengua.”

16 “... y se les leyó y acabó de leer y declarar el dicho día y otro siguiente...” 
as place names, and other minutiae, which were included in the final text (1988, p. 177). In the end, "They all agreed and said through the aforementioned interpreter that the said history was good and truthful, and according to what they knew and had heard their fathers and forefathers say..." (1988, p. 176) ${ }^{17}$ The kuraka even added the following comment: “ $\ldots$ they believed no other history ever written would be as certain and truthful as this one, because such a diligent examination had never been carried out before, nor had it been necessary to ask them anything, although they were the ones who knew the truth" (1988, p. 177) ${ }^{18}$. Unfortunately for the "truth," the 1988 edition of Sarmiento's text, which I am using, includes the following commentary in the Prologue: "An unclear incident, years later, ended in the death of the interpreter, Gonzalo Gómez Jiménez, when he dared to publicly declare the false information registered by superior order, changing the answers of the indigenous lords when writing them down. Before a judicial report was made of these affirmations, Gonzalo Gómez died of strangulation in a dungeon” (1988, p. 10). ${ }^{19}$ The editors do not say where they obtained this information, nor do they provide us with a citation or a written reference; they simply state the fact. If true, this transgression turns the whole act of authentication into a theatrical event, devised only to respect the appearances of certification, when in fact the truth was being trafficked (Pratt, 2002).

\section{The Inkas as Tyrants in Sarmiento's Text}

Tupac Inca Yupanki stands for the epitome of tyranny in Sarmiento's text: “... Tupac Inca Yupanqui, is the main and most atrocious tyrant of

17 "Y todos juntos se conformaron y dijeron por el dicho intérprete que la dicha historia estaba buena y verdadera y conforme a lo que ellos sabían y habían oído decir a sus padres y pasados...”

18 “...creían que ninguna otra historia que se haya hecho será tan cierta y verdadera como ésta, porque nunca se ha hecho tan diligente examinación, ni se les ha preguntado a ellos nada, que son los que pueden saber la verdad.”

19 "Un confuso incidente, años después, llevaría a la muerte al intérprete Gonzalo Gómez Jiménez, al pretender declarar públicamente las falsedades consignadas por orden superior, trocando al escribirlas las respuestas de los indígenas. Antes de que se llegara a levantar acta judicial de estas afirmaciones, Gonzalo Gómez murió agarrotado en un calabozo.” 
all” (Sarmiento, 1988, p. 23). ${ }^{20}$ He was a usurper of the power and governs in spite of his peoples: “... Pachacuti Inca Yupanqui ... dealt with government as the only Inca, without having been elected either by his father or peoples, but only by those who were close to him for and whose sole interest lied in receiving his bountiful gifts" (1988, p. 93). ${ }^{21}$ He was not lawfully elected: this fact only makes him a tyrant; furthermore, he was elected by those who had vested interests in supporting his unlawful government. His election is thus both irregular and tyrannical.

I wish to underline the fact that the giving of generous gifts is charged here with negative connotations. When Sarmiento describes the Spanish King, he also describes him as generous, but stresses the positive connotations of the fact: "Among the excellencies, sovereign and Catholic Phillip, who gloriously decorate princes, placing them in the highest point of estimation, that great father of Latin eloquence said that three were the greatest: largesse, benefit, and liberality" (1988, p. 17). ${ }^{22}$ Liberality, in the sixteenth century, refers to the fact that someone gives without expecting reciprocity, but also places the limits before being prodigal (Covarrubias, 1995, p. 713). Sarmiento goes on to say that "Giving is fit for Kings" (1988, p. 17). ${ }^{23}$

The negative generosity of the Inka is coupled with idolatrous stratagems which he devised to further attract those people under his tyrannical rule: "That is why he determined to adorn [Cuzco] with buildings and oracles, to frighten ignorant peoples and have them follow him entranced and stultified...” (1988, p. 95). ${ }^{24}$ Tyranny here is

${ }^{20}$ My translation of “... Tupac Inca Yupanqui, el mayor y más atroz y dañoso tirano de todos.”

21 “... Pachacuti Inca Yupanqui ... libraba como solo inca, sin elección de su padre ni pueblos, mas de por aquellos que se le habían allegado por el interés de las dádivas que hacía.”

22 "Entre las excelencias, soberano y católico Felipe, que gloriosamente a los príncipes decoran poniéndolos en sumo fastigio de estimación, dijo aquel padre de la elocuencia latina ser tres las mayores: largueza, beneficio y liberalidad.”

23 "Propio es de los reyes dar."

24 “Y por esto él determinó de la enguarnecer (Cuzco) en edificios y oráculos, para espantar las gentes ignorantes y traerlas imbuídas y abobadas tras sí...” 
based on dominion over people through idolatry. On the other hand, King Phillip is represented as the epitome of Christianity, and a Chosen One: "Of this glory, God Almighty gave Your Majesty such a great part that all the enemies of the holy Catholic Church of Christ our Lord tremble upon hearing your exalted name...” (1988, p. 18). ${ }^{25}$ The polarity between an idolatrous, unlawful leader and a Catholic one, chosen by God Himself following a dynastical order, is meant to further dramatize the differences between the two. This difference is best expressed as enmity, when Sarmiento recalls the deeds of King Phillip's ancestors, the Catholic Kings: “... the treasures God made your ancestors as distributors with such saintly magnanimity were spent in praiseworthy and saintly deeds, extirpating heretics, expelling the damn Saracens from Spain's boundaries...” (1988, p. 18). ${ }^{26}$ Heretics and Saracens were both enemies of the Catholic Kings; idolatrous indigenous leaders were tyrannical and the enemies of Phillip, the grandson of the Catholic Kings.

Inka Yupanqui's idolatry is carefully described and filled with details of black magic, and demonic practices: "That idol was chosen by Inca Yupanqui as a huauqui idol. He said he had come across him and spoken to him in an uninhabited, wild place, and that he had given him a two-headed serpent that he should carry with him always, saying that as long as he kept it with him no evil would hamper his endeavours” (1988, p. 96). ${ }^{27}$ Sarmiento expounds on the subject in describing the different types of cruel and often sanguinary practices related to the kind of idolatry practiced by the Inkas. He is especially careful to include information regarding the Capac Hucha, a ceremony in which children were offered to the gods: “... and having made their

25 “De esta gloria, Dios todopoderoso dio a Vuestra Majestad en esta vida tanta parte que de vuestro excelso nombre tiemblan todos los enemigos de la iglesia santa católica de Cristo nuestro señor...”

26 “... los tesoros de que Dios hizo expensores a vuestros mayores con tan santa magnanimidad los despendieron en loables y santas obras, extirpando herejes, lanzando los malditos sarracenos de los fines de España...”

27 "El cual ídolo tomó Inca Yupanqui por ídolo huauqui, porque decía que se había topado y hablado en un despoblado y que le había dado una culebra con dos cabezas, para que trajese siempre consigo, diciendo que mientras la trajese no le sucedería cosa siniestra en sus negocios.” 
sacrifices and calpa and having buried some children alive, which is called capa cocha, for the idols to favor that war..." (1988, p. 112). ${ }^{28}$ The actions described must have been, and still are, revolting for Catholics and Europeans in general. In a similar circumstance, Sarmiento again mentions the Capac Hucha: “... he offered many silver and gold treasures to the Sun, and to other oracles, and to the other huaca, and he also made the sacrifice of the capa cocha..." $\left(1988\right.$, p. 113) ${ }^{29}$. Sarmiento's descriptions and detailed information are geared towards scandalizing the King of Spain, and other Catholic readers of his report. He stresses the fact that the Inka is not only idolatrous, but that he sponsors and supports idolatrous behavior: “... he called on a man called Antarqui whom he had brought with himself in the conquests; these certify that this man was a great sorcerer, so great that he could fly in the air" (1988, p. 123).

Another source of scandal for the Catholic reader was the description of the Inka's sexual conduct. In Sarmiento's description, Inca Yupanqui goes from lechery (1988, p. 126) to incest, and then to homosexual practices: “... many times he took a widower as partner, and if this widower had a daughter that attracted him, he also took her as partner or lover". ${ }^{31}$ Regarding incest, it is interesting to note that Inka customs dealing with marriage or even kinship were not understood by Spaniards, who only saw them as contrary to Catholic dogma, as in the following example: “... he took all his sisters as lovers, saying that they could not possibly have a better husband than their brother" (1988, p. 127). ${ }^{32}$ In the area of Catholic sexual

28 “... y hechos sus sacrificios y calpa y enterrando algunos niños vivos, a que llaman capa cocha, porque sus ídolos favoreciesen en aquella guerra...”

29 “... ofreció muchos tesoros de plata y oro al Sol y a los demás oráculos y a los demás huacas e hizo además sacrificio de capa cocha...”

30 “... llamó a un hombre que traía consigo en las conquistas llamado Antarqui, el cual todos éstos afirman que era grande nigromántico tanto, que volaba por los aires.”

31 “... muchas veces tomaba a alguna viuda por mujer, y que si esta viuda tenía alguna hija que le agradase, la tomaba también por mujer o manceba.”

32 “... tomaba a todas sus hermanas por mancebas, diciendo que no podían tener mejor marido que a su hermano.” 
relationships, Sarmiento constructs the figure of the King as regulator of the offending situations: "Your Majesty and your ancestors, most saintly kings, prevented innocent men from being sacrificed, and human flesh from being eaten, the damned execrable $\sin ,{ }^{33}$ and the indifferent lying $^{34}$ with sisters and mothers, the abominable use of beasts, and their nefarious and damned customs" (1988, p. 23). ${ }^{35}$ This construction is possible because the King is described as the epitome of Christianity: “... most Christian King...." ${ }^{36} \mathrm{He}$ is such a defender of the faith that he "deserves to be called vigor of the Church" (1988, p. 18). ${ }^{37}$ Catholic ideology supersedes all other ways of thinking and behaving, establishing the parameters which serve to measure all other customs, berating other cultural values.

Another aspect of the construction of Inka tyranny I wish to explore is that of government. The description of a good governor falls upon the King of Spain, who is characterized as powerful and glorious. This positive image is obtained through the widening of the territory under his control, and the quantity of subjects under his command: “... in a great empire there is great glory", 38 and "... the glory of a King consists in having many vassals, and his dejection in the diminishing of his people” (1988, p. 18). ${ }^{39}$ Regarding Inka Pachacuti, Sarmiento's expressions are less benevolent: "In those victories Pachacuti was most cruel with the vanquished, and with these cruelties he had people so terrorized that in panic of being eaten by beasts, or

33 "Damned execrable sin" and "pecado nefando" are sixteen century metaphors for homosexual activity.

34 “Lying” and “concúbitos” are sixteen century metaphors for coitus and rape.

35 "Vuestra Majestad y sus antepasados reyes santísimos impidieron sacrificar los hombres inocentes y comer carne humana, el maldito pecado nefando y los concúbitos indiferentes con hermanas y madres, abominable uso de bestias y las nefarias y malditas costumbres suyas...”

36 “... Cristianísimo Rey...”

37 “mereceis ser llamado vigor de la iglesia."

38 “... en gran imperio es gran gloria.”

39 “... la gloria del rey consiste en tener muchos vasallos, y su abatimiento en la disminución del pueblo.” 
burnt, or cruelly tormented, they surrendered and obeyed him, those who were not able to resist him with weapons" (1988, p. 105). ${ }^{40}$ The author stresses the fact of tyranny, where people are forced to accept a leader: "It should be noted that, even though some provinces say that they voluntarily gave in and obeyed, it was because of the reasons mentioned, and because he sent messengers with threats of devastation if not served and obeyed by them" (1988, p. 105). ${ }^{41}$ The situation described is one of desolation and despair under Inka Yupanqui in Tawantinsuyu: “... seeing the violence and oppression that the Cuzco Inka imposed, everywhere and to every nation, without pardoning anyone, following his example many sinchi wanted to do the same in other parts... in a way that in this kingdom everything was in a tyrannical, confusing state where no one in his own town could count even on his own neighbor" (1988, p. 105). ${ }^{42}$ Inkas and sinchi are thus presented as generators of violence and chaos, and their government is seen as the source of insecurity and disorder. The contrast with the territory governed by the King of Spain is striking, even though historical facts speak to the contrary in both cases.

One of the most opprobrious faults in a European kingdom is the attempt to eliminate members of the Royal Family. It is close to regicide - the assassination of a King or Queen-a terrible sin indeed. If the King is magnanimous and protects his subjects, no one would even consider eliminating he who was appointed by God to occupy this high position. Sarmiento's Inka Yupanqui is not only a cruel assassin, but kills members of his own family when they are seen as prospective rivals. The author does not spare any adjectives in his representation of

40 "Era en esos vencimientos Pachacuti cruelísimo con los vencidos, y con estas crueldades tenía las gentes espantadas de tal manera, que de miedo de no ser comidos de las fieras o quemados o cruelmente atormentados, se le rendían y obedecían, los que no eran para le resistir por armas.”

41 "Y es de notar por esto que, aunque algunas provincias dicen que de su voluntad se le dieron y obedecieron, fue por la causa y razón dicha y porque los enviaba a amenazar que los asolaría si no le venían a servir y obedecer.”

42 “... viendo las violencias y fuerzas que el inca del Cuzco por todas partes a todas naciones, sin perdonar a nadie, hacía, a su ejemplo muchos sinchis habían querido hacer lo mismo en otras partes ... de manera que ya en este reino todo era una confusa behetrìa tiránica, que nadie en su pueblo estaba seguro aún de su propio ciudadano.” 
the Inka as the vilest leader: “... where his brothers reached him [Inka Urco] and killed him off. And from here Inca Yupanqui and Inka Rocca with their followers went to Caquia Xaquixahuana to see their father, but he never wanted to see or talk to them because of the anger he held against them for Inca Urco's death” (1988, p. 98). ${ }^{43}$ Inka Yupanqui’s father reacts as the King of Spain would; this contrasts with the Inka's behavior, stressed as unacceptable by his own father, and by Sarmiento in the name of the King. In this sequence, Inka Yupanqui is represented as an assassin who has committed fratricide. In the following quotation, the Inka is, as a consequence of the previous atrocity, a parricide of the King of Spain: “And Inca Viracocha [Yupanqui's father], within a very short time, died of the anger produced by Inca Urco's death. He died as a private person, deprived of all honor and patrimony..." (1988, p. 98). ${ }^{44}$ The clarification of the deprivation in which Yupanqui's father falls raises the question of who deprived him of "honor and patrimony." All signs point to a son's responsibility, that of Yupanqui. Even worse, Sarmiento might imply that Inka Yupanqui stripped his own father of glory and riches.

Yupanqui's fratricidal anger does not stop after killing Inka Urco: it continues with other brothers who had the misfortune of being outstanding, thus generating Yupanqui's envy. This passage is quite telling: "It was known by Inca Yupanqui that he had gained so many lands, treasures, and honors that he felt envious towards him, and furthermore, as they say, was afraid of him, and he looked for excuses to kill him" (1988, p. 109). ${ }^{45}$ Sarmiento is referring to the assassination of another of Inka Yupanqui's brothers, Capac Yupanqui. In this case, as well as in the killing of another brother, Huayna Yupanqui, he does not perform the killings himself, but asks his followers to carry them out (1988, p. 109). In order to properly fill the figure of tyrant, a King

43 “... adonde le alcanzaron sus hermanos y le acabaron de matar. Y desde aquì Inca Yupanqui e Inca Rocca con su gente fueron a Caquia Xaquixahuana a ver al padre, mas nunca los quiso ver ni hablar por el enojo que tenía contra ellos por la muerte de Inca Urco.”

44 “El Inca Viracocha, al cabo de poco tiempo, murió de enojo por la muerte de Inca Urco, privado y despojado de toda honra y hacienda...”

45 "Lo cual sabido por Inca Yupanqui que habìa ganado tantas tierras, tesoros y honra, túvole envidia y aún, según dicen, temor, y buscó achaques para lo matar." 
or leader must commit atrocities towards his own family, when a possible source of competitors to the throne or seat of power. The tyrant gets rid of them all so as to govern or reign without the threat of lawful dynastical descendants who could question his accession to power.

An example of scandalous behavior from a Catholic king's perspective is that of the leader "adored" by his people. Since only God can receive the treatment of adoration, the human being who expects to be treated as a god is full of the capital sin of pride or hubris. The story of the angel who claimed to be as great as God and was condemned to burn in hell is exemplary in this sense. Inca Yupanqui exhibits this behavior, according to Sarmiento: "And at this point he ordered that everyone who came to see him should adore him and bring an offer with him...” (1988, p. 116). ${ }^{46}$ Sarmiento also gives us an example of this adoration: “... Amaru Tupa Inca ... fell on his face on earth and adored him and made sacrifices to him and obeyed him” (1988, p. 117) ${ }^{47}$ There is no explanation to clarify if these activities were part of the protocols of interaction in a theocracy, in a society in which their leaders were also the high priests, the interlocutors of the gods, and should be treated with what they believed was utmost respect. This treatment was interpreted as the sinful manifestation of pride by Catholics.

The picture is thus of a despicable man, the anti-leader, the enemy of Catholic Kings and their descendants. The picture is sharper still because of the contrast with that of the King of Spain himself presented as the epitome of saintly behavior. Inca Yupanqui's representation, designed to demonstrate to the King that he has made a great contribution to the peoples of the Indies by conquering them and liberating them from the scourge of their leaders, is outright shocking, especially to a Catholic reader. It cannot be understated that this representation includes all the negative traces a Catholic author could conceive of to transmit the worst possible image of a person. This horrible portrait contributed, then, to appease the anxiety pangs generated in the King's conscience by news of atrocities committed

46 "Y para entonces mandó que nadie le viniese a ver que no le adorase y trajese algo en las manos que le ofreciese..."

47 “... Amaru Tupa Inca ... cayó sobre su faz en tierra y adorole e hízole sacrificios y obedecióle.” 
against indigenous peoples who were supposedly his subjects. Also, the rise in indigenous mortality rates, with the concomitant reduction of taxes levied, had alerted the Crown to serious problems in the Indies which affected the kingdom's arks.

\section{The Historian as an Agent of Colonization Aided by Interpreters and Translators}

Sarmiento's typification of Inka Yupanqui and his descendants as tyrants does not cease to stun researchers in spite of contextual explanations and historical justifications. How far can a subject go to please his King? As far as an outright invention of reality? He was able to project such a representation, different from its actual source, because the "reality" he was conveying would never be seen by his reader. This void facilitates the transition from description to fictionalization.

It is important to determine which were the terms and conditions of that editing. The twisted reading of the translated version is an equivocal rendering of facts that could not have been accepted by kuraka. So, the oral version they heard must have said one thing, and the written text must have said another. Anyway, at this point in time and in historical occurrences, it was a text that would never be read by any of the indigenous leaders present in the authentication ceremony without the intervention of a Spanish mediator. It is interesting to note here that Sarmiento speaks of an indigenous report that was "glossed in reverse" (1998, p. 124) by other indigenous peoples. He was well aware of that possibility, and that it truly served his own ends.

Sarmiento moved in the Andes among translators and scribes. He translated some phrases and texts from Latin, being himself an educated person. But he remains silent before indigenous languages. This is when he needs interpreters to convey his needs to witnesses, and to record their agreement to what was written in his history. The sources he used to write his Historia General were probably already written, since he speaks of "compiling" and "editing," not questioning or interviewing. He does not indicate who his interpreters were, if any. This lack of information about the translation work does not invalidate the requirement of having used their services. If Sarmiento's text was based on histories written before his time, these were definitely translated. On the other hand, he gives plenty of details about the tasks 
involved in the reading, translation, and authentication of the edited information.

Sarmiento's text is an exemplary exercise of a biased construct. Every translation generates a representation, be it the reproduction of the one found in the source text, or one that appears only in the target text. This is what Sarmiento produced. I believe his editing work was the key to the twisted representation his written version offers. What was authenticated was a version "glossed in reverse" and read to the kuraka, not what we find in Sarmiento's text. Only a stratagem, a trick or a lie could have made the kuraka approve a version such as Sarmiento's. Sarmiento's twisted version helped create the figure of the tyrannical Inkas, a singular example of the fictionalization of history which results when the colonizer is the one writing it.

\section{Universidad Femenina del Sagrado Corazón UNIFE Pontificia Universidad Católica del Perú}

\section{References}

COVARRUBIAS, Sebastián ([1611] 1995). Tesoro de la lengua castellana y española. Madrid, Ed. Castalia.

FOSSA, Lydia (2005). "Betanzos, Sarmiento y Quipocamayos: una familia de textos," in Construyendo historias. Aportes para la historia hispanoamericana a partir de las crónicas. Lima, Pontificia Universidad Católica del Perú and Universidad de Estudios Extranjeros de Osaka, pp. 297-338.

GONZÁLEZ HOLGUÍN, Diego ([1608] 1989). Vocabulario de la lengua Qquichua o del Ynga. Lima, 3rd. Fac. Ed., Universidad Nacional Mayor de San Marcos.

LOHMANN VILLENA, Guillermo (1984). "Propuestas de solución de juristas y políticos," in Francisco de Vitoria y la Escuela de Salamanca. La ética en la conquista de América. Madrid, Consejo Superior de Investigaciones Científicas, pp. 631-657. 
MORALES PADRÓN, Francisco (1979). Teoría y Leyes de la Conquista. Madrid, Ed. Cultura Hispánica, Centro Iberoamericano de Cooperación.

NOWACK, Kerstin (2002). "Las intenciones del autor: Juan de Betanzos y la Suma y narración de los Incas.” Revista Andina, No. 34, pp. 47-64.

PÉREZ FERNÁNDEZ, Isacio (1986). Bartolomé de las Casas en el Perú. El espíritu lascasiano en la primera evangelización del imperio incaico. 1531 - 1573. Cuzco, CERA Bartolomé de las Casas.

PEREÑA, Luciano (1984). "La escuela de Salamanca y la duda indiana," in Francisco de Vitoria y la escuela de Salamanca. La ética en la conquista de América. Madrid, Consejo Superior de Investigaciones Científicas, pp. 291-344.

PRATT, Mary Louise (2002). "The Traffic in Meaning. Translation, Contagion, Infiltration.” Profession 2002, Journal of the Modern Language Association of America (MLA), pp. 25-36.

SANTO TOMÁS, Domingo de ([1560]1951). Lexicon o vocabulario de la lengua general del Perú. Valladolid, Fernández de Córdova, Lima, Ed. Fac, Universidad Nacional Mayor de San Marcos.

SARMIENTO DE GAMBOA, Pedro ([1572] 1988). Historia General llamada Indica. Madrid, Miraguano Ed. and Ed. Polifemo.

\begin{abstract}
The Inkas as Tyrants: The Construction of a Twisted Representation - The chronicler Pedro Sarmiento de Gamboa wrote a history of the Inkas in 1571 proving that they had been tyrants. This was necessary to convince the King that he had every right to appropriate their lands, riches, and peoples. It is an excellent example of how a representation does not necessarily have to match what actually happened when political issues are at stake. My article analyzes that twisted representation and explores the motives Sarmiento had for kuraka to authenticate his version.
\end{abstract}

RÉSUMÉ : Les Incas perçus comme tyrans: la construction d'une représentation trompeuse - Le chroniqueur Pedro Sarmiento de Gamboa écrivit en 1571 une histoire des Incas pour prouver leur tyrannie. La chose était nécessaire pour convaincre le Roi qu'il avait 
tous les droits sur leurs terres, leurs biens et leur peuple. Cette chronique constitue un bon exemple du travail de représentation: celle$\mathrm{ci}$, en effet, lorsque les questions politiques priment, ne doit pas nécessairement refléter la réalité. Mon article analyse cette représentation trompeuse et explore les motifs pour lesquels Sarmiento dut faire authentifier sa version des faits par les kuraka.

Keywords: Inka tyranny, Indian doubt (duda indiana), New Laws, kuraka, interpreters or lenguas.

Mots-clés : tyrannie inka, doute indien (duda indiana), nouvelles lois, kuraka, interprètes ou lenguas.

Lydia Fossa: Universidad Femenina del Sagrado Corazón UNIFE, Pontificia Universidad Católica del Perú, Universidad Nacional Mayor de San Marcos, Calle Santa Luisa 195/603, Lima 27, Perú.

Email: lydiafos@yahoo.com 